\title{
Diet of the squid Moroteuthis ingens (Teuthoidea: Onychoteuthidae) in the upper slope waters of the Kerguelen Islands
}

\author{
Yves Cherel $^{1, *}$, Guy Duhamel ${ }^{2}$ \\ ${ }^{1}$ Centre d'Etudes Biologiques de Chizé, UPR 1934 du Centre National de la Recherche Scientifique, \\ 79360 Villiers-en-Bois, France \\ ${ }^{2}$ Département des Milieux et Peuplements marins, Muséum National d'Histoire Naturelle, 43 rue Cuvier, \\ 75231 Paris Cedex 05, France
}

\begin{abstract}
The diet of the onychoteuthid squid Moroteuthis ingens was investigated through stomach content analyses of 72 individuals collected aboard a trawler targeting Patagonian toothfish Dissostichus eleginoides in the upper slope waters of the Kerguelen Archipelago. M. ingens is primarily piscivorous ( $67 \%$ by number and $87 \%$ by reconstituted mass), although the diet also includes squids (12 and $12 \%$, respectively) and crustaceans (21 and $<1 \%$, respectively). The main fish prey were the paralepidid Arctozenus risso (28\% by reconstituted mass), the gempylid Paradiplospinus gracilis (24\%) and various myctophids. $M$. ingens preyed also upon conspecifics (cannibalism, $6 \%$ ), and the euphausiid Euphausia triacantha was the main crustacean item. Most of the prey are pelagic organisms performing diurnal migration, suggesting that the benthopelagic $M$. ingens catch them when they are near the bottom during the day. In turn, $M$. ingens is a prey for several species of top predators, including $D$. eleginoides and air-breathing vertebrates. $M$. ingens thus contributes to carbon export from the pelagic environment to the benthos and from the ocean to the atmosphere as carbon dioxide expired by birds and mammals.
\end{abstract}

KEY WORDS: Benthos $\cdot$ Cephalopod $\cdot$ Mesopelagic fish $\cdot$ Pelagos $\cdot$ Predator Resale or republication not permitted without written consent of the publisher

\section{INTRODUCTION}

Squids of the family Onychoteuthidae (Oegopsida) are among the most abundant and ecologically important cephalopod species in the Southern Ocean. Onychoteuthids are major prey items for many species of top predators, including fishes, seabirds and marine mammals (Clarke 1983, Cherel \& Weimerskirch 1999). However, little is known about their basic biology, including their food and feeding ecology and thus, trophic relationships in the marine ecosystems. This is due predominantly to the lack of oceanographic cruises devoted to squid collection along with the difficulty of sampling such organisms that actively avoid fishing gear.
Moroteuthis ingens is a subantarctic circumpolar species, occurring in the outer shelf and slope waters surrounding Southern Ocean islands (Crozet, Kerguelen, Heard and Macquarie), southern South America and the Falkland Islands, and New Zealand and its adjacent subantarctic islands (Nesis 1987). Unlike other onychoteuthids, its occurrence and abundance at the bottom in the lower sublittoral and bathyal make $M$. ingens a bycatch in commercial and research trawling (Jackson et al. 1998a, 2000b), which has contributed to studies on its biology. Studies in New Zealand have demonstrated that the species is annual, undergoes an ontogenic migration from pelagic to benthopelagic waters and is a terminal spawner (Jackson 1993, 1997, Jackson \& Mladenov 1994). Analysis of 
stomach contents showed that large individuals of $M$. ingens are primarily piscivorous, feeding mainly on mesopelagic fish in New Zealand waters and at Macquarie Island (Jackson et al. 1998b, Phillips et al. 2001).

The aim of the present study was to investigate the food spectrum of Moroteuthis ingens in Kerguelen waters. $M$. ingens is the main bycatch squid species in the bottom trawl fishery targeting the Patagonian toothfish Dissostichus eleginoides in the upper slope waters surrounding the archipelago. In the southern Indian Ocean (Crozet, Kerguelen and Heard), its role in the ecosystem is reflected by its importance in the diet of apex predators. There, $M$. ingens is a main food for the commercially important Patagonian toothfish (authors' unpubl. data), large seabirds such as the king penguin Aptenodytes patagonicus and wandering albatross Diomedea exulans (Cherel et al. 1996, Moore et al. 1998, Cherel \& Weimerskirch 1999), and the southern elephant seal Mirounga leonina (Green \& Burton 1993). A better knowledge of subantarctic marine ecosystems therefore requires determining the prey and trophic level of this abundant and voracious feeder that potentially consumes in excess of $10 \%$ of its body mass per day (Jackson et al. 1998b).

\section{MATERIALS AND METHODS}

Eighty-seven individuals of Moroteuthis ingens were collected from the commercial vessel 'Kerguelen de
Tremarec' by French fishery observers in summer/fall 1995 and 1996. Squids were taken as bycatch from bottom trawls targeting Patagonian toothfish in slope waters (500 to $900 \mathrm{~m}$ ) in the NE Kerguelen Archipelago. All individuals were frozen on board and returned to a laboratory in France for analysis. They were weighed and measured (dorsal mantle length, DML). Squids were allocated a maturation stage according to Jackson \& Mladenov (1994). Of the 87 individuals, 52 were males and 35 were females. Two size classes were found for each sex which, together with their maturity stages, allow to differentiate 4 different groups of squids: immature and mature males, and immature and maturing females (Table 1, Fig. 1). Immature males and females were of similar size (mean DML and body mass, M: $157 \mathrm{~mm}$ and $144 \mathrm{~g}$, respectively), but maturing females were larger than mature males (mean DML and M: 255 vs $235 \mathrm{~mm}$, and 593 vs $404 \mathrm{~g}$, respectively). There was no overlap in size between immature and larger mature males, nor between immature and larger maturing females.

Fifteen individuals $(17 \%)$ had no food in their stomach. The whole stomach of the remaining 72 specimens was sorted and weighed, and mass of its content was calculated as the difference between the full and empty stomach masses. Stomach contents of maturing females were heavier than those of the 3 other groups (Table 1). Relative to body mass, the mass of stomach contents was, however, not significantly different among the 4 groups of squids. The fact that cephalo-

Table 1. Moroteuthis ingens. Biological characteristics of specimens caught in Kerguelen waters during the summer/fall period. Data are means \pm SD with ranges in parentheses. Values in same column not sharing a common superscript letter are significantly different $(\mathrm{p}<0.05)$

\begin{tabular}{|c|c|c|c|c|c|}
\hline $\begin{array}{l}\text { Sex and stage } \\
\text { of maturity* }\end{array}$ & $\begin{array}{l}\text { Mantle length } \\
\text { (mm) }\end{array}$ & $\begin{array}{l}\text { Body mass } \\
\text { (g) }\end{array}$ & $\begin{array}{c}\text { Occurrence of } \\
\text { empty stomach (\%) }\end{array}$ & $\begin{array}{l}\text { Stomach content } \\
\text { (g) }\end{array}$ & $\begin{array}{l}\text { Stomach content } \\
(\% \text { of body mass })^{* *}\end{array}$ \\
\hline \multicolumn{6}{|l|}{ Males } \\
\hline Immatures $(n=25)$ & $\begin{array}{c}24 \\
155 \pm 19^{\mathrm{a}} \\
(112-188)\end{array}$ & $\begin{array}{c}24 \\
137 \pm 43^{\mathrm{a}} \\
(59-227)\end{array}$ & $\begin{array}{c}5 \\
20.0\end{array}$ & $\begin{array}{c}20 \\
8.4 \pm 8.4^{\mathrm{a}} \\
(1.2-27.9)\end{array}$ & $\begin{array}{l}19 \\
6.5 \pm 4.8 \\
(0.7-17.6)\end{array}$ \\
\hline Matures $(\mathrm{n}=27)$ & $\begin{array}{c}27 \\
235 \pm 18^{b} \\
(191-267)\end{array}$ & $\begin{array}{c}24 \\
404 \pm 67^{\mathrm{b}} \\
(252-506)\end{array}$ & $\begin{array}{c}6 \\
22.2\end{array}$ & $\begin{array}{c}21 \\
12.0 \pm 8.9^{\mathrm{a}} \\
(1.9-36.2)\end{array}$ & $\begin{array}{c}19 \\
3.3 \pm 2.7 \\
(0.8-11.0)\end{array}$ \\
\hline \multicolumn{6}{|l|}{ Females } \\
\hline Immatures $(n=18)$ & $\begin{array}{c}18 \\
161 \pm 18^{\mathrm{a}} \\
(133-191)\end{array}$ & $\begin{array}{c}18 \\
154 \pm 46^{\mathrm{a}} \\
(85-258)\end{array}$ & $\begin{array}{c}2 \\
11.1\end{array}$ & $\begin{array}{c}16 \\
6.4 \pm 4.6^{\mathrm{a}} \\
(1.1-18.7)\end{array}$ & $\begin{array}{c}16 \\
4.8 \pm 4.4 \\
(1.3-19.4)\end{array}$ \\
\hline Maturing $(\mathrm{n}=17)$ & $\begin{array}{c}17 \\
255 \pm 21^{\mathrm{c}} \\
(214-286)\end{array}$ & $\begin{array}{c}15 \\
593 \pm 138^{\mathrm{c}} \\
(341-856)\end{array}$ & $\begin{array}{c}2 \\
11.8\end{array}$ & $\begin{array}{c}15 \\
23.6 \pm 17.7^{b} \\
(1.0-71.2)\end{array}$ & $\begin{array}{c}13 \\
4.5 \pm 3.5 \\
(1.2-13.9)\end{array}$ \\
\hline Statistics & $\begin{array}{c}F_{3,82}=155.07 \\
\mathrm{p}<0.0001\end{array}$ & $\begin{array}{c}F_{3,77}=147.27 \\
p<0.0001\end{array}$ & $\begin{array}{l}\chi^{2}{ }_{3}=1.43 \\
\mathrm{p}=0.698\end{array}$ & $\begin{array}{c}F_{3,68}=8.25 \\
\mathrm{p}<0.0001\end{array}$ & $\begin{array}{c}F_{3,63}=2.25 \\
\mathrm{p}=0.091\end{array}$ \\
\hline
\end{tabular}



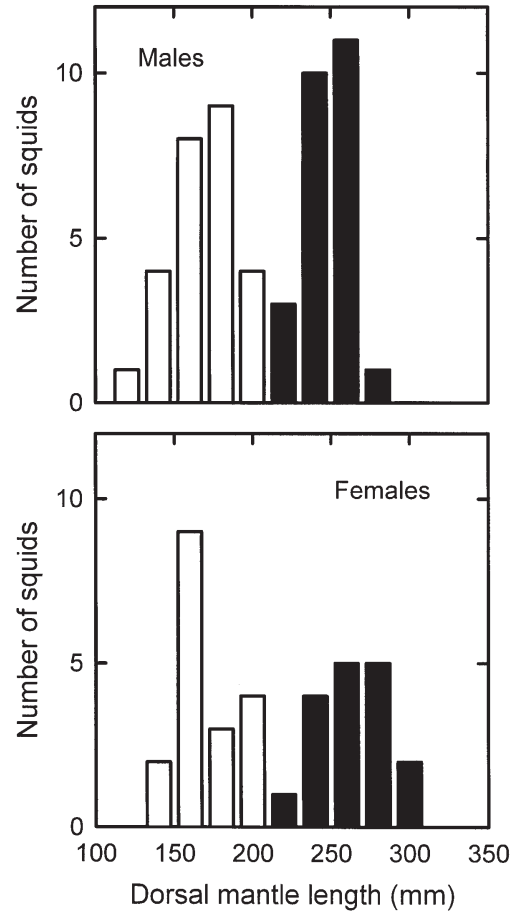

Fig. 1. Moroteuthis ingens. Numerical distribution of dorsal mantle length (DML) of immature (white) and mature (black) males, and immature (white) and maturing (black) females

pod beaks bite off small pieces of prey precluded dividing and weighing broad prey classes (crustaceans, fish and squids) to calculate their proportion by fresh mass in the diet. We did, however, determine the dominant prey class of the stomach contents visually.

Identification of prey relied on the examination of otoliths and bones for fish, beaks for cephalopods and exoskeletons for crustaceans. Since otoliths of some fish species (Arctozenus risso, Paradiplospinus gracilis) were rarely found in stomach contents, special care was taken to use all fish hard parts (including scales) with an emphasis on some distinctive bones (vertebrae, opercles, teeth), in order to identify items to the lowest possible taxon (Cherel et al. 2000). Items were identified by comparison with material held in our own collection and by reference to the available literature, including Williams \& McEldowney (1990) for fish, Clarke (1986) for cephalopods, and Baker et al. (1990) and Razouls (1994) for crustaceans. Length of uneroded or slightly eroded otoliths (OL) of fish and of lower beaks (LRL) of squids were measured with a vernier caliper or using an ocular scale in a binocular microscope. Fish standard length (SL), cephalopod DML and $\mathrm{M}$ were calculated using regression equations (Clarke 1986, Adams \& Klages 1987, Williams \& McEldowney 1990, Cherel et al. 1997, Olsson \& North 1997, authors' unpubl. data). For the few species where no relationships were available, DML, SL and M were estimated using equations for closely related species or for species with a similar morphology. Dietary data are presented using 3 calculation techniques, namely the frequency of occurrence and percentages by number and by reconstituted mass of each prey type, as is usually done in food analysis for seabirds (see e.g. Cherel et al. 2000).

Data were statistically analysed using SYSTAT 9 for WINDOWS (Wilkinson 1999). Values are means \pm SD.

\section{RESULTS}

Overall, fish dominated the diet of Moroteuthis ingens both by number $(67 \%)$ and by reconstituted mass $(87 \%)$, squids ranking second (12 and $12 \%$, respectively), and crustaceans third (21 and $<1 \%$, respectively). A total of 337 prey items from 24 different species, including 14 fishes, 5 squids and 5 crustaceans, were identified (Table 2). At the family level, diet was dominated by myctophid fishes with 9 identified species and 143 individuals $(42 \%$ by number and $33 \%$ by reconstituted mass). The analysis of the frequency of occurrence and the percentages by number and reconstituted mass indicated that the prey species fell into 3 categories: (1) The main prey species were the paralepidid Arctozenus risso, the gempylid Paradiplospinus gracilis and to a lesser extent the myctophid Gymnoscopelus piabilis, which constituted 28, 24 and $15 \%$ of the diet by reconstituted mass, respectively. (2) Common prey species, which were found in more than $5 \%$ of the samples and amounted to between 3 and $7 \%$ by number and/or $>1 \%$ by mass, were the myctophids Electrona carlsbergi, Krefftichthys anderssoni, Protomyctophum andriashevi and $P$. bolini, the channichthyid Champsocephalus gunnari, the squids Moroteuthis ingens and Slosarczykovia circumantarctica, and the crustacean Euphausia triacantha. The latter krill species was the main prey item identified in 3 stomach contents from small squids. (3) Rare prey species, including 4 myctophids, 2 other fishes, 3 squid species, the amphipod Themisto gaudichaudii and copepods, accounted for low proportions of the overall diet. Copepods, and probably other items such as Euphausia sp., were apparently fish prey secondarily ingested by squids. Noticeable was the occurrence in the dietary samples of a few scales of the Patagonian toothfish with no other remains from that species. Scales were from large fish targeted by the fishery, thus suggesting that squids ingested them during trawling time.

Crustaceans dominated in stomach contents of some small individuals, fish in those of the majority of the specimens and squids in those of some large indi- 
viduals (crustaceans: $\mathrm{DML}=136 \pm 17 \mathrm{~mm}, \mathrm{n}=4$; fish: $\mathrm{DML}=200 \pm 46 \mathrm{~mm}, \mathrm{n}=57 ;$ squids: $\mathrm{DML}=232 \pm$ $49 \mathrm{~mm}, \mathrm{n}=10$; Kruskall-Wallis test $=11.76, \mathrm{p}=0.003$; Mann-Whitney tests, $U=169.5,20.0$ and 1.0, and $\mathrm{p}=$
$0.042,0.006$ and 0.007 when comparing DML of individuals with stomach contents containing mainly fish vs squids, crustaceans vs fish and crustaceans vs squids, respectively).

Table 2. Moroteuthis ingens. Frequency of occurrence, numbers and reconstituted mass of prey items identified from stomach contents (total for all 72 samples pooled)

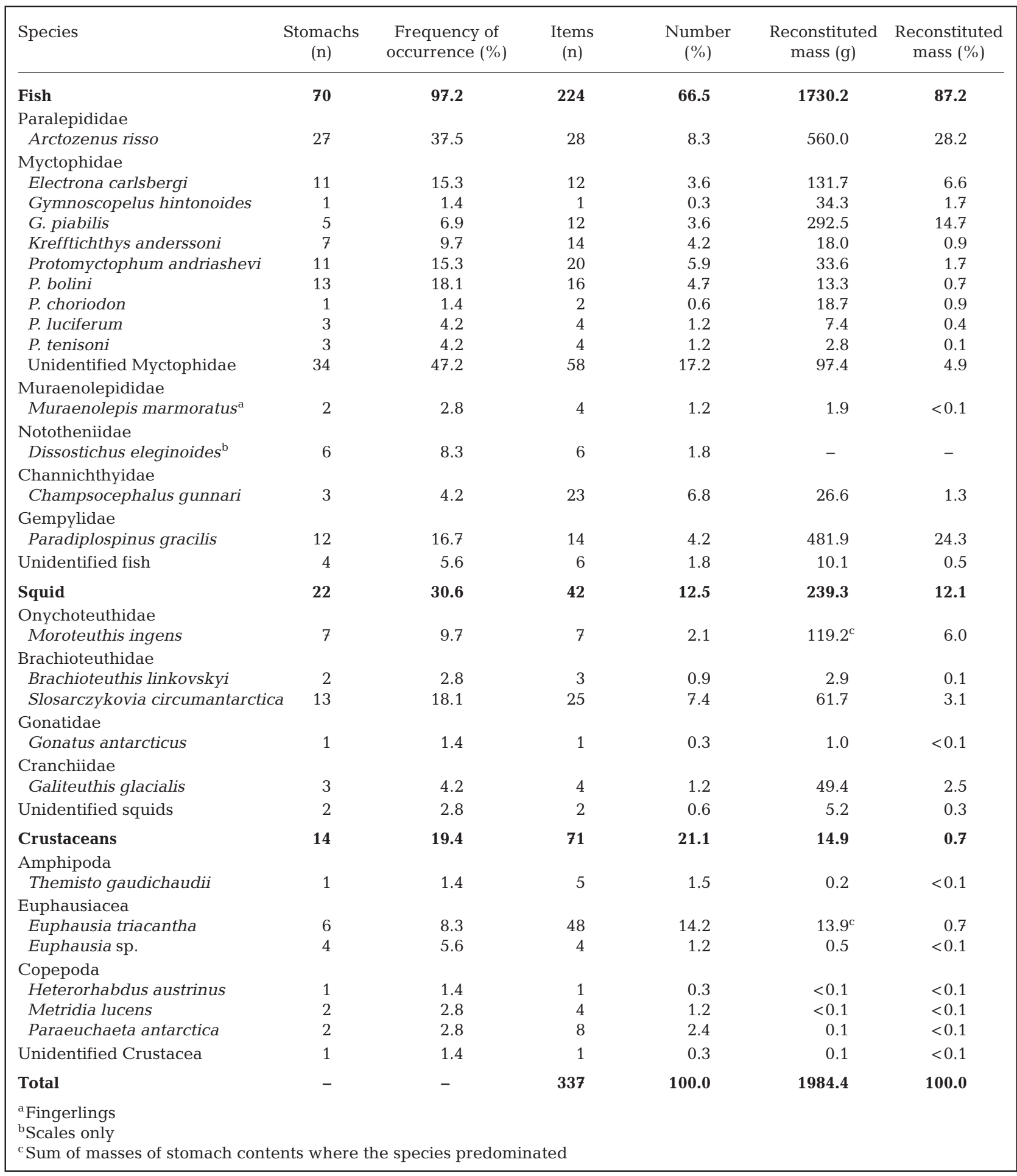


Table 3. Moroteuthis ingens. Measured fish mandible length (ML), otolith length (OL), and squid lower rostral length (LRL), and estimated fish standard length (SL), squid dorsal mantle length (DML) and body mass (M) of the main prey identified from stomach contents. Values are means $\pm \mathrm{SD}$ with ranges in parentheses

\begin{tabular}{|c|c|c|c|c|c|}
\hline \multirow[t]{2}{*}{ Species } & \multirow[t]{2}{*}{$\mathrm{n}$} & \multicolumn{2}{|c|}{ Measured parameters (mm) } & \multirow{2}{*}{$\begin{array}{l}\text { SL/DML } \\
\text { (mm) }\end{array}$} & \multirow{2}{*}{$\begin{array}{l}M \\
(g)\end{array}$} \\
\hline & & Parameters & Values & & \\
\hline \multicolumn{6}{|l|}{ Fish } \\
\hline \multirow[t]{2}{*}{ Arctozenus risso } & 2 & OL & $3.5-3.7$ & $198 \pm 91(94-257)$ & $-{ }^{\mathrm{a}}$ \\
\hline & 1 & ML & 8.4 & & \\
\hline Electrona carlsbergi & 11 & OL & $4.0 \pm 0.2(3.7-4.5)$ & $89 \pm 5(83-100)$ & $11.0 \pm 2.0(8.5-15.6)$ \\
\hline Gymnoscopelus hintonoides & 1 & OL & 4.4 & $-{ }^{\mathrm{a}}$ & $-{ }^{\mathrm{a}}$ \\
\hline G. piabilis & 10 & OL & $5.3 \pm 0.4(4.8-6.0)$ & $126 \pm 8(115-141)$ & $23.9 \pm 4.6(17.8-33.4)$ \\
\hline Krefftichthys anderssoni & 10 & OL & $1.5 \pm 0.2(1.1-1.8)$ & $47 \pm 9(33-59)$ & $1.2 \pm 0.6(0.3-2.2)$ \\
\hline Protomyctophum andriashevi & 14 & OL & $2.1 \pm 0.1(1.8-2.3)$ & $52 \pm 1(49-54)$ & $1.7 \pm 0.1(1.4-1.8)$ \\
\hline P. bolini & 16 & OL & $1.6 \pm 0.2(1.3-2.0)$ & $38 \pm 6(30-49)$ & $0.8 \pm 0.4(0.4-1.6)$ \\
\hline P. choriodon & 2 & OL & $1.9-2.5$ & $64-91$ & $3.5-15.2$ \\
\hline$P$. luciferum & 3 & OL & $2.3 \pm 0.5(1.7-2.6)$ & $54 \pm 5(48-57)$ & $1.9 \pm 0.5(1.3-2.2)$ \\
\hline P. tenisoni & 3 & OL & $1.3 \pm 0.0(1.3-1.4)$ & $41 \pm 2(39-43)$ & $0.7 \pm 0.1(0.6-0.8)$ \\
\hline Muraenolepis marmoratus & 3 & ML & $3.5 \pm 0.2(3.4-3.7)$ & $-c^{a}$ & $-c^{a}$ \\
\hline Champsocephalus gunnari & 2 & ML & $7.3-7.5$ & $63-65$ & $1.1-1.2$ \\
\hline Paradiplospinus gracilis & 3 & OL & $3.2 \pm 0.1(3.1-3.2)$ & $314 \pm 11(301-321)$ & $34.4 \pm 4.3(29.4-37.2)$ \\
\hline \multicolumn{6}{|l|}{ Squids } \\
\hline Brachioteuthis linkovskyi & 2 & LRL & $0.6-0.7$ & $29-30$ & $0.9-1.0$ \\
\hline Slosarczykovia circumantarctica & 13 & LRL & $1.2 \pm 0.8(0.4-2.8)$ & $41 \pm 17(23-72)$ & $2.6 \pm 2.4(0.4-7.3)$ \\
\hline Gonatus antarcticus & 1 & LRL & 1.0 & 31 & 1.0 \\
\hline Galiteuthis glacialis & 2 & LRL & $1.5-2.3$ & $73-106$ & $5.3-14.7$ \\
\hline
\end{tabular}

Estimated body length indicated that Moroteuthis ingens fed on a prey spectrum with a wide range in size (Table 3). According to their size, items can be grouped in 3 categories: (1) Large prey (length: >90 mm; mass: >10 g) include Paradiplospinus gracilis, Arctozenus risso, Gymnoscopelus piabilis and Electrona carlsbergi. $M$. ingens itself (cannibalism) is a part of that group, as indicated by the size of its broken beaks in stomach contents. (2) Medium-sized prey (length: 30 to $60 \mathrm{~mm}$; mass: 0.5 to $3.0 \mathrm{~g}$ ) are the commonest items. Most of the myctophid fishes and squids belong to that group. (3) Small prey are crustacean species. They were broken into small pieces, thus precluding any measurement. Available information, however, indicates that a few Themisto gaudichaudii are longer than $20 \mathrm{~mm}$ in Kerguelen waters (Bocher et al. 2001), and that adults Euphausia triacantha measured 25 to $30 \mathrm{~mm}$ (Baker 1959). For both species, body masses are $<0.2 \mathrm{~g}$.

\section{DISCUSSION}

The 2 size classes of Moroteuthis ingens in Kerguelen waters were similar to those found at the Falkland Islands over the year (Jackson et al. 1998a) and in the diet of seabirds from Crozet Islands (Cherel \&
Weimerskirch 1999). The co-occurrence of mature males and maturing females in upper-slope waters is also in agreement with the population structure elsewhere, with mature females descending to greater depths to spawn (Jackson 1997).

At Kerguelen, Moroteuthis ingens is primarily piscivorous, preying mainly upon the paralepidid Arctozenus risso, the gempylid Paradiplospinus gracilis and various species of myctophids. A. risso and P. gracilis were not previously recorded in the diet of $M$. ingens, but feeding on myctophids is in general agreement with the dietary habits obtained on larger individuals than those from the present study at the 2 other localities so far investigated. At Macquarie (and to a lesser extent Heard Island), both direct identification of prey items and the biochemical analysis of lipids from the squid digestive gland indicate that myctophids are an important prey group for $M$. ingens (Phillips et al. 2001). In New Zealand waters, the most abundant species were the myctophid Lampanyctodes hectoris and viperfish Chauliodus sloani and/or dragon fish Stomias boa (Jackson et al. 1998b). Squid rank second in the diet of $M$. ingens with no identified species in the previous studies (Jackson et al. 1998b, Phillips et al. 2001), but, like at Kerguelen, cannibalism has been observed at the Falklands and it was suspected to occur in New Zealand (Jackson et al. 1998b). 


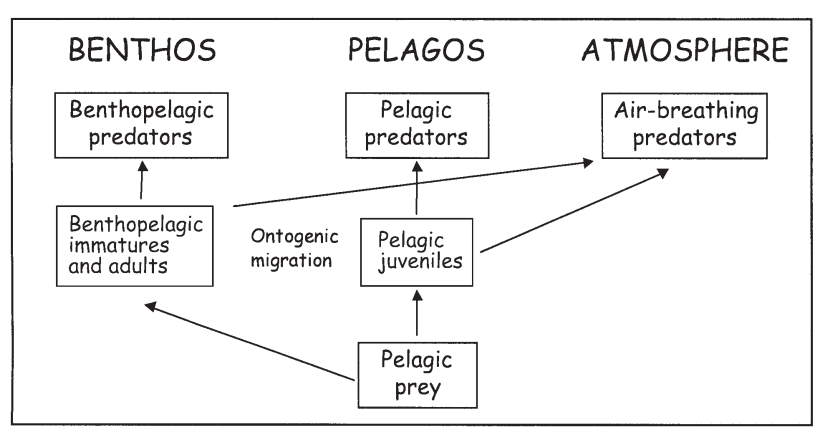

Fig. 2. Moroteuthis ingens. Energy pathways between benthos, pelagos and atmosphere

Crustaceans were considered as items secondarily ingested by large Moroteuthis ingens from the stomachs of fish (Phillips et al. 2001), and this is also the likely explanation for the presence of some crustaceans in the dietary samples from Kerguelen. Crustaceans were, however, the primary prey of some small specimens (112 to $152 \mathrm{~mm} \mathrm{DML}$ ). Interestingly, statolith microstructure of $M$. ingens suggests a habitat shift from the pelagic to the benthopelagic zone, and that settlement takes place at or before $160 \mathrm{~mm}$ DML (Jackson 1993). Taken together, the data suggest that juvenile $M$. ingens undergo both a habitat and a dietary shift at about the same DML. Due to the small sample size, however, further investigations about the feeding habits of juvenile $M$. ingens are needed to test this hypothesis.

At Kerguelen, Moroteuthis ingens exploits its environment at various trophic levels: herbivorous macrozooplankton (Euphausia triacantha), mesozooplanktonic feeders (small species of myctophids), macrozooplanktonic/micronektonic feeders (Arctozenus risso, Paradiplospinus gracilis, large myctophids) and larger carnivorous organisms (cannibalism). It is clear that $M$. ingens feed on pelagic organisms. E. triacantha is a mesopelagic species of krill (Baker 1959), A. risso is oceanic, spawning at slopes and banks (Post 1990), and $P$. gracilis (= P. antarcticus) is pelagic (benthopelagic) at shelves and slopes (Nakamura \& Parin 1993). Antarctic and subantarctic myctophids are meso-pelagic (Hulley 1990), and most of the myctophids eaten by $M$. ingens are common in Kerguelen waters (Duhamel 1998). Another general characteristic of its prey is that they perform diurnal migration (Baker 1959, Duhamel 1998, Duhamel et al. 2000), some of them (e.g. Gymnoscopelus piabilis) being known to be epibenthic during the day (Hulley et al. 1989). Two hypotheses present themselves to account for the presence of pelagic animals in the diet of a benthopelagic predator: $M$. ingens either preys upon pelagic migrators at the bottom during the day or, alternatively, it performs vertical migration to feed in the water column. The first hypothesis is the more plausible because, unlike other onychoteuthids (Kondakovia longimana and Moroteuthis knipovitchi), $M$. ingens was not caught in midwater research trawls targeting myctophids in the area (authors' unpubl. data). Either way, because of its high abundance and biomass, the species is probably a key organism in the transfer of energy from the pelagic to the benthic subantarctic environment in outer shelves and slope waters (Fig. 2) (Jackson et al. 1998b).

In turn, dietary investigations indicate that Moroteuthis ingens is an important item for some apex predators in the southern Indian Ocean. Juveniles are the main winter prey of king penguins from Crozet and Heard islands (Cherel et al. 1996, Moore et al. 1998, Cherel \& Weimerskirch 1999). At that time, king penguins also feed on various myctophids, including the species eaten by $M$. ingens at Kerguelen (Cherel et al. 1996), thus suggesting that penguins feed within the same slope community of organisms as that described in the present study. $M$. ingens is commonly found in the diet of the abundant slope Patagonian toothfish at Crozet and Kerguelen islands (authors' unpubl. data) and is the main squid species in the diet of elephant seals at Heard Island (Green \& Burton 1993). Finally, adult $M$. ingens (probably dead or dying post-spawn individuals), together with adult Kondakovia longimana, are the major prey of wandering albatrosses at Crozet (Cherel \& Weimerskirch 1999).

Elsewhere in the Southern Ocean, Moroteuthis ingens was found in the diet of the giant squid Architeuthis dux (Förch 1998), the epipelagic slender tuna Allothunnus fallai (Yatsu 1995) and pelagic southern opah Lampris immaculatus (Jackson et al. 2000a). The 2 fishes prey on juveniles, indicating that $M$. ingens is common in open pelagic waters where the species may play a significant trophic role before its settlement at the bottom. $M$. ingens was also reported in the diet of various air-breathing vertebrates (review in Jackson et al. 1998a, Cherel \& Weimerskirch 1999), including for example the royal albatross Diomedea epomophora and sperm whale Physeter catodon in New Zealand (Clarke \& Roper 1998, Imber 1999) and the pilot whale Globicephala melaena at Tierra del Fuego (Clarke \& Goodall 1994). Hence, the squid participates in the carbon export from the Southern Ocean marine ecosystems to the atmosphere as carbon dioxide expired by birds and mammals (Fig. 2). The life cycle and biology of $M$. ingens illustrates the complexity of marine food webs, because the species is linked to the energy fluxes between the pelagos, benthos and atmosphere, depending on its development stage and trophodynamic relationships (Fig. 2). 
Acknowledgements. The authors thank fishery observers from the Terres Australes et Antarctiques Françaises for collecting squids in the field, the shipowner COMATA for sending the samples to the laboratory in France, C. Trouvé for her help in stomach content analysis and S. Razouls for identifying copepods.

\section{LITERATURE CITED}

Adams NJ, Klages NT (1987) Seasonal variation in the diet of the king penguin (Aptenodytes patagonicus) at subAntarctic Marion Island. J Zool 212:303-324

Baker A de C (1959) The distribution and life history of Euphausia triacantha Holt and Tattersall. Discov Rep 29: 311-339

Baker A de C, Boden BP, Brinton E (1990) A practical guide to the euphausiids of the world. Natural History Museum Publications, London

Bocher P, Cherel Y, Labat JP, Mayzaud P, Razouls S, Jouventin P (2001) Amphipod-based food web: Themisto gaudichaudii caught in nets and by seabirds in Kerguelen waters, southern Indian Ocean. Mar Ecol Prog Ser 223: 261-276

Cherel Y, Weimerskirch H (1999) Spawning cycle of onychoteuthid squids in the southern Indian Ocean: new information from seabird predators. Mar Ecol Prog Ser 188: 93-104

Cherel Y, Ridoux V, Rodhouse PG (1996) Fish and squid in the diet of king penguin chicks, Aptenodytes patagonicus, during winter at sub-antarctic Crozet Islands. Mar Biol 126:559-570

Cherel Y, Guinet C, Tremblay Y (1997) Fish prey of Antarctic fur seals Arctocephalus gazella at Ile de Croy, Kerguelen. Polar Biol 17:87-90

Cherel Y, Weimerskirch H, Trouvé C (2000) Food and feeding ecology of the neritic-slope forager black-browed albatross and its relationships with commercial fisheries in Kerguelen waters. Mar Ecol Prog Ser 207:183-199

Clarke MR (1983) Cephalopod biomass-estimation from predation. Mem Natl Mus Vic 44:95-107

Clarke MR (1986) A handbook for the identification of cephalopod beaks. Clarendon Press, Oxford

Clarke MR, Goodall N (1994) Cephalopods in the diets of three odontocete cetacean species stranded at Tierra del Fuego, Globicephala melaena (Traill, 1809), Hyperoodon planifrons Flower, 1882 and Cephalorhynchus commersonii (Lacepede, 1804). Antarct Sci 6:149-154

Clarke MR, Roper CFE (1998) Cephalopods represented by beaks in the stomach of a sperm whale stranded at Paekakariki, North Island, New Zealand. S Afr J Mar Sci 20:129-133

Duhamel G (1998) The pelagic fish community of the Polar Frontal Zone off the Kerguelen Islands. In: di Prisco G, Pisano E, Clarke A (eds) Fishes of Antarctica: a biological overview. Springer-Verlag, Berlin, p 63-74

Duhamel G, Koubbi P, Ravier C (2000) Day and night mesopelagic fish assemblages off the Kerguelen Islands (Southern Ocean). Polar Biol 23:106-112

Förch EC (1998) The marine fauna of New Zealand: Cephalopoda: Oegopsida: Architeuthidae (Giant Squid). Natl Inst Wat Atmos Res (NIWA) Biodivers Mem 110:1-113

Green K, Burton HR (1993) Comparison of the stomach contents of southern elephant seals, Mirounga leonina, at Macquarie and Heard Islands. Mar Mamm Sci 9:10-22 Hulley PA (1990) Myctophidae. In: Gon O, Heemstra PC

Editorial responsibility: Otto Kinne (Editor),

Oldendorf/Luhe, Germany (eds) Fishes of the Southern Ocean. JLB Smith Institute of Ichthyology, Grahamstown, p 146-178

Hulley PA, Camus P, Duhamel G (1989) Ichthyological results of cruise MD-42/SIBEX-II. Part 1. Fishes from RMT-8 stations, with additional records of lanternfishes (Myctophidae: Osteichthyes) from the Indian and Atlantic sectors of the Southern Ocean. Cybium 13:83-99

Imber MJ (1999) Diet and feeding ecology of the royal albatross Diomedea epomophora - king of the shelf break and inner slope. Emu 99:200-211

Jackson GD (1993) Growth zones within the statolith microstructure of the deepwater squid Moroteuthis ingens (Cephalopoda: Onychoteuthidae): evidence for a habitat shift? Can J Fish Aquat Sci 50:2366-2374

Jackson GD (1997) Age, growth and maturation of the deepwater squid Moroteuthis ingens (Cephalopoda: Onychoteuthidae) in New Zealand waters. Polar Biol 17:268-274

Jackson GD, Mladenov PV (1994) Terminal spawning in the deepwater squid Moroteuthis ingens (Cephalopoda: Onychoteuthidae). J Zool 234:189-201

Jackson GD, George MJA, Buxton NG (1998a) Distribution and abundance of the squid Moroteuthis ingens (Cephalopoda: Onychoteuthidae) in the Falkland Islands region. Polar Biol 20:161-169

Jackson GD, McKinnon JF, Lalas C, Ardern R, Buxton NG (1998b) Food spectrum of the deepwater squid Moroteuthis ingens (Cephalopoda: Onychoteuthidae) in New Zealand waters. Polar Biol 20:56-65

Jackson GD, Buxton NG, George JA (2000a) Diet of the southern opah Lampris immaculatus on the Patagonian Shelf; the significance of the squid Moroteuthis ingens and anthropogenic plastic. Mar Ecol Prog Ser 206:261-271

Jackson GD, Shaw AGP, Lalas C (2000b) Distribution and biomass of two squid species off southern New Zealand: Nototodarus sloanii and Moroteuthis ingens. Polar Biol 23: 699-705

Moore GJ, Robertson G, Wienecke B (1998) Food requirements of breeding king penguins at Heard Island and potential overlap with commercial fisheries. Polar Biol 20:293-302

Nakamura I, Parin NV (1993) Snake mackerels and cutlassfishes of the world. FAO species catalogue, Vol 15. FAO, Rome

Nesis KN (1987) Cephalopods of the world. Squids, cuttlefishes, octopuses and allies. TFH Publications, Neptune City, NJ

Olsson O, North AW (1997) Diet of the king penguin Aptenodytes patagonicus during three summers at South Georgia. Ibis 139:504-512

Phillips KL, Jackson GD, Nichols PD (2001) Predation on myctophids by the squid Moroteuthis ingens around Macquarie and Heard Islands: stomach contents and fatty acid analyses. Mar Ecol Prog Ser 215:179-189

Post A (1990) Paralepididae. In: Gon O, Heemstra PC (eds) Fishes of the Southern Ocean. JLB Smith Institute of Ichthyology, Grahamstown, p 138-141

Razouls C (1994) Manuel d'identification des principales espèces de copépodes pélagiques antarctiques et subantarctiques. Ann Inst Océanogr 70:3-204

Wilkinson L (1999) SYSTAT 9 for Windows. SPSS, Chicago

Williams R, McEldowney A (1990) A guide to the fish otoliths from waters off the Australian Antarctic Territory, Heard and Macquarie Islands. ANARE (Aust Natl Antarct Res Exped) Res Notes 75:1-173

Yatsu A (1995) The role of slender tuna, Allothunnus fallai, in the pelagic ecosystems of the South Pacific Ocean. Jpn J Ichthyol 41:367-377

Submitted: September 17, 2002; Accepted: January 23, 2003 Proofs received from author(s): March 10, 2003 